\section{New Officers and Council Elected}

Robert Jervis, Adlai E. Stevenson Professo $r$ of International Politics at Columbia University, became the Association's 97th president on September 2 at the annual Business Meeting of the Association. Robert O. Keohane of Duke University presented Jervis with the Association gavel. Joining Jervis in guiding the Association are five new Officers and eight council members.

Jervis received his Ph.D. from the University of California, Berkeley in 1968. He has served the Association

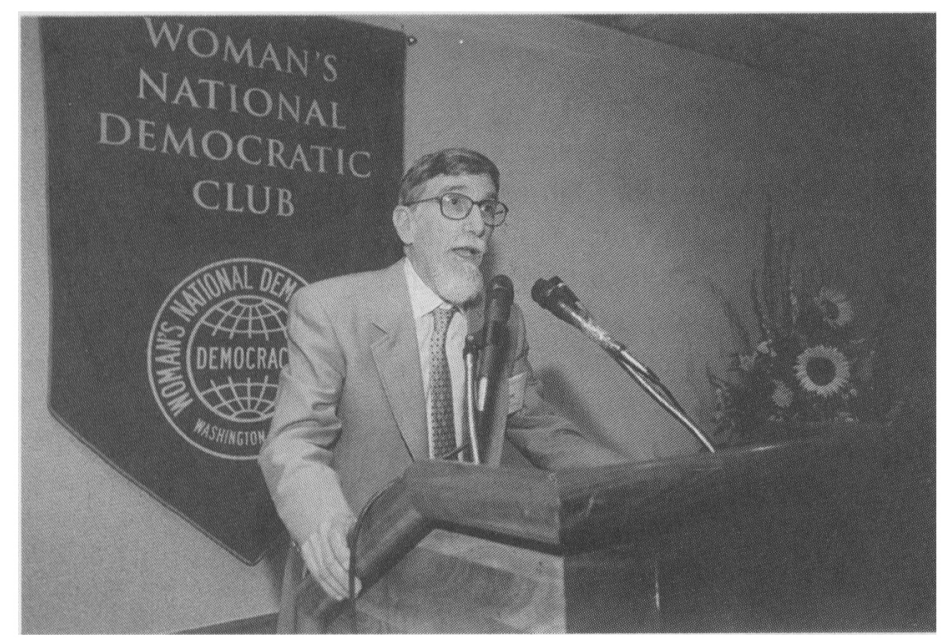

2001 APSA President. Robert Jervis, Columbia University, addresses attendees at the 2000 Honors Reception. Jervis will serve as president through the 2001 Annual Meeting in San Francisco. chapters and articles. eyer Award for Ideas Improving World Order. Jervis is also the author of Perception and Misperception in International Politics (Princeton University Press, 1976), The Logic of Images in International Relations (Princeton University Press, 1970; 2nd ed., Columbia University Press, 1989), and The Illogic of American Nuclear Strategy (Cornell University Press, 1984). He has coedited eight other books and authored over 80

Assuming the position of president-elect is Robert Putnam of Harvard University. As Peter and Isabel Malkin Professor of Public Policy at

Harvard, he teaches both graduate and undergraduate courses in American politics, international relations, comparative politics, and public policy. $\mathrm{He}$ is the founder of The Saguaro Seminar: Civic Engagement in America, a program that has brought together leading practitio-

in many ways, including as a member of the Council, as a vice president, and as a program chair for the 1987 Annual Meeting. He was a Guggenheim fellow in 1978-79 and is a fellow of the American Association for the Advancement of Science and the American Academy of Arts and Sciences. At Columbia, Jervis teaches courses ranging from the introductory undergraduate survey to the advanced research seminar. He has previously taught at Harvard and UCLA. His System Effects: Complexity in Political Life (Princeton University Press, 1997) was a cowinner of APSA's political psychology section's best book award and The Meaning of the Nuclear Revolution (Cornell University Press, 1989) won him the 1990 Grawem- ners and thinkers for a multiyear discussion of broad-scale, actionable ideas for fortifying America's civic connectedness.

Putnam's previous Association responsibilities have included service as vice president and as a member of the Council, the Program Committee, and the Task Force on Civic Education. While department chair at Harvard, he was active in APSA's efforts to increase minority graduate enrollment. A former dean of the John F. Kennedy School of Government, he has also served as associate dean of the Faculty of Arts and Sciences and director of the Center for International Affairs. Before going to Harvard in 1979, Putnam taught at the University of Michigan and served on the staff of the National
Security Council. Raised in a small town in the Midwest, he graduated from Swarthmore College in 1963, attended Balliol College, Oxford, and received his Ph.D. from Yale University in 1970.

The other officers for 2000-2001 are:

Vice Presidents: Valerie Bunce, Cornell University; Mark Schneider, University at Stony Brook-SUNY; and Susan Welch, Pennsylvania State University

Secretary: Judith Stiehm, Florida International University

The newly elected members of the Council, APSA's governing body, are: Richard Brody, Stanford University; Robert Holmes, Clark Atlanta University; Robert Kaufman, Rutgers University; L. Sandy Maisel, Colby College; Doris Marie Provine, Syracuse University; Kathryn Sikkink, University of Minnesota; Katherine Tate, University of California, Irvine; and Margaret Weir, University of California, Berkeley.

\section{"Planning Our Future" Receives Extended Council Discussion}

Ohio State University's Paul Beck, chair of the Strategic Planning Committee, presented "Planning Our Future: The Report of the APSA's Strategic Planning Committee" to the Council at its August meeting. Noting that refining many of the proposals set forth in the report will take several years and fully implementing any accepted recommendations would taken even longer, APSA President and Duke University Professor Robert Keohane accepted the report for consideration and encouraged APSA members to read it and to share their comments and ideas (planning@apsanet.org).

In their discussion, Council members paid specific attention to the proposed Mission Statement, which they will consider for adoption in April 2001, and the possibilities for expanding the contents of the Association's journals or developing a third journal. Members also commented on the proposals regarding 
the Annual Meeting and issues of representation and governance.

\section{Other Actions}

The Council commended the SPC for its excellent report, approved the budget for FY2001 presented by Treasurer James Stimson (see accompanying Treasurer's Report), approved a series of proposals from the Annual Meeting Committee but asked the committee to reconsider the two-appearance rule, clarified the guidelines concerning eligibility for dissertation awards, and approved the formation of a new Or- ganized Section on Comparative Democratization.

The complete draft minutes of the August 31 Council meeting are printed in the Gazette section of this issue of $P S$.

\section{Council Votes to Expand APSA Journals}

After a spirited debate at its August 31 meeting, the APSA Council unanimously approved the following motion.

The APSA will publish expanded book reviews and more integrative essays no later than

\section{Lee Sigelman Chosen as Next APSR Editor}

Lee Sigelman, professor of political science and Columbian Professor, George Washington University, was unanimously approved by the Council to serve as the next editor of the American Political Science Review. Sigelman will begin his three-year term on September 1, 2001.

APSA President Robert Keohane proposed Sigelman, who was the unanimous choice of the editorial search committee composed of Peter Gourevitch, chair, University of California, San Diego; Robert Jervis, Columbia University; Gary King, Harvard University; Arlene Saxonhouse, University of Michigan, Ann Arbor; and Katherine Tate, University of California, Irvine. Commenting on the work of the committee, Keohane said, "In my judgment, it did its work extremely well: thoroughly, fairly, collegially, and expeditiously."

Sigelman is a former editor of American Politics Quarterly and a current deputy editor of Social Science Quarterly. He has served as chair of the political science departments at the University of Kentucky and George Washington University, and is author or coauthor of eight books and over 200 articles in refereed journals, several of which have appeared in the APSR. The fields in which he has published include comparative politics, public opinion/political behavior, bureaucracy and administration, the study of political executives, and methodology.

Sigelman "clearly has the requisite abilities and personal characteristics for an editor of the Review," Keohane wrote in his memo to the Council. "He writes well. . . . communicates effectively with people in other subfields of the discipline, and enjoys reaching out to different constituencies. He . will ensure that manuscripts flow quickly to reviewers and will read them promptly and thoroughly himself."

Keohane said that he wanted to make sure that the person he nominated to be editor "understands the depth and breadth of criticism of the Review in the profession. It is clear to me that he does. . . I think that his combination of energy, openness, and commitment to the highest standards of scholarship will make him a great editor."

Lee Sigelman's memo to the Council briefly explicating his vision and plans for APSR can be found at wuw.apsanet.org/new/ sigelmanplan.cfm.
January 2003 in a form-electronic and/or print, in an existing or new publication-to be decided. An ad hoc Publications Implementation Committee, appointed by the president and approved by the Council will be established to recommend to the Council plans to carry out this resolution. The committee will report to the Council at its next meeting, April 21, 2001, and will have a completed plan in place for Council approval in time for its August 29, 2001 meeting.

This motion arose in the context of the report of the Strategic Planning Committee, "Planning Our Future" (reprinted in this issue of $P S$ ), and a competing proposal of the Publications Committee concerning the creation of a new journal. APSA President Robert Jervis, Columbia University, has named Helen Milner, chair, Columbia University; William J. Ball, The College of New Jersey; Gary King, Harvard University; Jeffrey Legro, University of Virginia; Cheryl Miller, University of Maryland, Baltimore County; Bert Rockman, University of Pittsburgh; and Lee Sigelman, George Washington University, to the ad hoc committee. Members of the Publications Implementation Committee and Council must make several substantive decisions rapidly if they are to formulate a realistic, fundable plan for discussion by the membership in the summer of 2001 and for adjustments and approval by the end of August. Foremost among these is, "Will there be a separate journal?"

If the committee members determine a new journal should be developed, they must then decide what, if anything, it should incorporate. In other words, they must specify how its offerings would differ from or complement those of APSA's existing print journals, $A P S R$ and $P S$, and its online materials on APSAnet. Specifc questions they will have to address include: Would it be wise to strip the highly popular book reviews from the $A P S R$, making these the heart of the new journal? Might doing so risk leaving the discipline's flagship journal with a shrinking audience? And, might the new journal include state-of-thediscipline essays, literature reviews, 